\title{
ЗМІСТ ПОНЯТТЯ «СУГЕСТІЯ» В НАУКОВИХ ДОСЛІДЖЕННЯХ МИНУЛОГО ТА СУЧАСНОСТІ
}

Міщанчук В. М. Зміст поняття «сугестія» в наукових дослідженнях минулого та сучасності.

У статті розглядається зміст поняття «сугестія», аналізується роль свідомих і несвідомих механізмів навіювання. Вивчається досвід використання сугестії в педагогіці, розкривається значення сугестійних технологій у професійній підготовці майбутніх учителів музики.

Ключові слова: сугестія, свідоме, несвідоме, сугестологія, майбутній учитель музики.

Мищанчук В. Н. Содержание понятия «суггестия» в научных исследованиях прошлого и современности.

В статье рассматривается содержание понятия «суггестия», анализируется роль сознательных и бессознательных механизмов внушения. Изучается опыт использования суггестии в педагогике, раскрываєтся значение суггестивных технологий профессиональной подготовке будущих учителей музыки.

Ключевые слова: суггестия, сознательное, бессознательное, суггестология, будущий учитель музыки.

Mischanchuk V. N. The concept of «suggestion» in the scientific research of the past and present.

The article considers the concept «suggestion», examines the role of conscious and unconscious mechanisms of suggestion, reveals the experience of suggestive technologies use in teachers of music professional training.

Key words: suggestion, conscious, unconscious, suggestologiya, future teacher of music.

На сучасному етапі розвитку нашої держави відбуваються бурхливі зміни в усіх галузях суспільства. Для здійснення цих перетворень необхідні висококваліфіковані спеціалісти. Важливим і особливо актуальним в Україні постає питання про підвищення рівня підготовки майбутніх учителів у зв'язку з потребою у фахівцях високого рівня духовної, естетичної та моральної культури, які б активно брали участь у науковому та культурному житті країни, творчо підходили до розв'язання поставлених перед ними завдань. Тому вагомого значення в підготовці майбутніх учителів набуває використання новітніх методів та технологій, які б сприяли не тільки кращому засвоєнню навчального матеріалу, а й розвитку творчих здібностей, налагодженню комунікативних зв'язків між учасниками педагогічного процесу. На нашу думку, таким сучасним методом є сугестія.

Аналіз наукової літератури дозволяє констатувати, що сугестія привертала до себе увагу дослідників різних галузей науки. Вивченню питань сугестії присвятили свої праці психологи: Т. Ахмедов, I. Бернгейм, В. Бехтерєв, М. Бурно, Г. Гончаров, У. Джеймс, Є. Джекобсон, В. Куліков, А. Льебо, І. Монахова, А. Свядощ, І. Шульц та ін. Представники грузинської школи психологів Н. Адамашвили, І. Бжалава, В. Норакідзе, А. Прангишвілі, Д. Узнадзе, Б. Хачапуридзе, 3. Ходжава займались дослідженням та визначенням ролі в сугестії такого механізму, як психологічна установка. У філософських працях А. Адлера, Г. Гемгольца, Ф. Гербарта, 3. Фрейда, А. Шопенгауера, К. Юнга розглядаються свідомі й несвідомі механізми навіювання. Питання про різні сфери діяльності душі людини знайшли своє відображення у наукових працях І. Зязюна, М. Лещенко, Дж. Мерфі, Т. Рейзенкінд, С. Рубінштейна, П. Симонова. Дослідженнями в області фізіології вищої нервової діяльності, пов'язаною з сугестією, займались І. Павлов, І. Сеченов, О. Ухтомський. Вивченню сугестивних аспектів мови присвятили свою увагу Б. Алякринський, Б. Велічковський, О. Журавльов, Н. Мечковська, В. Налімов, С. Степанова, І. Черепанова, Л. Якубинський. Педагоги-науковці С. Гончаров, Г. Китайгородська, Г. Лозанов, С. Пальчевський, А. Сиротенко, І. Шехтер уважають, що використання сугестії в навчально-виховному процесі дозволить збільшити обсяги засвоєння учбового матеріалу, сприятиме налагодженню спілкування між учасниками педагогічного процесу та всебічному розвитку особистості. Питанню сугестії в підготовці майбутніх музичних фахівців присвятили свою увагу В. Петрушин, О. Полякова, А. Козир, Т. Рейзенкінд, В. Федоришин. 
Meта статmі - розглянути зміст категорії «сугестія» в дослідженнях минулого та сучасності та визначити ії роль у підготовці майбутніх учителів музики.

У Давньоруській та церковнослов'янській мовах спостережуваним є слово «вьноушати» («навіювати»), що означає почути, упровадити у свідомість [11, с. 8]. Навіювати що кому (воушать?) у тлумачному словнику Даля означає вселяти, передавати, переконувати, поселяти в думках, змусити думати, сприймати передану інформацію словами або іншим способом [2, с. 217].

Психолог В. Куліков уважає, що «навіювання в загальному вигляді можна уявити як психологічний вплив, який здійснюється за допомогою мовлення і немовленєвих засобів та відрізняється зниженою орієнтацією» $[11$, с. 8$]$.

Важливими психологічними механізмами сугестії є свідоме і несвідоме. Значний внесок у дослідженні несвідомого було зроблено психоаналізом. 3. Фрейд у роботі «Несвідоме» розробив концепцію несвідомого розуму і вважав, що в людині співіснують дві свідомості. Науковець уважав, що всі психічні процеси починаються з несвідомого. Щодо свідомості, то 3. Фрейд стверджує, що «свідомістю $є$ поверхневий шар душевного апарату» і називає ії «Я» [9, с. 17]. Він створив топографічну модель розуму, яка складалась зі свідомості, передсвідомості та несвідомого, а пізніше замінює іiі на структурну модель, де несвідоме становить систему розуму, а не тільки має місце в просторі. У новій концепції особистість $є$ поєднанням трьох різних психічних систем - «Ід», «Его» i «Суперего». Сукупністю несвідомих бажань, інстинктів та потягів $є$ «Ід».

Послідовником ідей досліджень несвідомого був видатний науковець К. Юнг, який стверджував, що несвідоме складається 3 двох шарів, а саме 3 особистого несвідомого і надособистого (колективного) несвідомого. Особисте несвідоме характеризується як суб'єктивно-психічне, його зміст складають витіснені обтяжливі уявлення, втрачені спогади, які не досягли свідомості, тому що були недостатньо сильними і також включає змісти, які ще для свідомості не дозріли. Колективне несвідоме є об'єктивно-психологічним, віддалене від особистого і має загальнолюдські, початкові образи і мотиви, які називає архетипами. Він уважає, що на основі початкових образів і формуються найвідоміші думки людства. На думку К. Юнга, застосування під час сугестії надзвичайно впливової сили початкових образів має особливу дію на свідомість суб'єкта і може зумовити досить серйозні зміни у ньому [12].

П. Симонов також займався дослідженнями площини свідомого й несвідомого і розподіляє останнє на такі категорії як підсвідоме й надсвідоме. Під свідомістю науковець розуміє «таке знання про світ, закріплене в «нервових моделях» мозку, яке: 1) може бути використаним людиною для організації дій, направлених на задоволення потреб, що є у нього; 2) може бути переданим іншим членам співтовариства за допомогою другої (мови) сигнальної системи» [7, с. 46]. До підсвідомості науковець відносить зовнішнє вираження відтінків емоцій, неусвідомлювані деталі рухів, рефлекси. Творче перетворення навколишнього середовища, потреба особистості у пошуках нової інформації, на думку П. Симонова $є$ особливістю індивіда, яка він називає надсвідомістю.

Т. Рейзенкінд уважає, що свідоме і несвідоме людини повинні розглядатись у взаємозв'язку. Саме в науковому та творчому процесі це поєднання відіграє значну роль $\mathrm{i}$ впливає на формування образного мислення, сприяє утворенню особистісних смислів.

Питаннями сугестії займались також видатні лінгвісти. Так, дослідник О. Журавльов вивчаючи фонетичну значущість тексту, підкреслив, що вона «впливає на читача, збільшуючи вірогідність тих або інших його суджень і оцінок, причому цим впливом можна управляти» [3, c. 73]. Він зазначає, що фоносемантика діє на підсвідомому рівні людини i «навчаючи комп'ютер фоносемантиці, ми ніби конструюємо якийсь аспект мовної підсвідомості, мовної інтуїції комп'ютера» [3, с. 147]. Тому комп'ютер можна використовувати як помічникаконсультанта для посилення впливу на людину за допомогою мови.

I. Черепанова, досліджуючи питання сугестивної лінгвістики, зазначає, що сугестія є багаторівневою системою, охоплює багато дисциплін, які перебувають у тісному взаємозв'язку. Сугестія, на думку науковця, може бути як звичайним компонентом людського спілкування, так і спеціально організованим маніпулятивним видом комунікації за допомогою використання вербальних і невербальних засобів [10, с. 115]. І. Черепанова вважає, що під час аналізу функціонування сугестивних текстів у визначеному культурологічному середовищі необхідне звернення до міфу як до вторинної семіотичної системи. Дослідниця разом з іншими 
співробітниками лабораторії сугестивної лінгвістики доопрацювали комп’ютерну програму фоносемантичного аналізу тексту й застосували їі для вивчення універсальних і індивідуальних сугестивних текстів, здвйснили порівняльний аналіз гетеро- та автосугестивних текстів. Науковець уважає, що завдяки аналізу сугестивних текстів можливе свідоме моделювання як на структурному, так і на фонологічному рівні рекламних, лікувальних і навчальних текстів.

Спочатку навіювання та гіпноз застосували психотерапевти у своїй практиці для лікування хворих. Одним із перших, хто запропонував використовувати гіпнотизм для корекції моральних якостей дитини, був лікар Берильйон. Значний внесок у розроблення застосування навіювання в педагогічному процесі зробили В. Бехтерев, А. Свядощ, А. Ковальов, С. Кравко, В. М'ясищев, А. Токарський, Б. Хачапурідзе. Так В. Бехтерев, говорячи про навіюваність у дітей, зазначає, що «...особлива вразливість дітей перебуває у тісному зв'язку з незвичайною їх навіюваністю, завдяки якій дитині легко прищепити як все негативне, так і позитивне» [1, c. 153]. Проблеми застосування навіювання і самонавіювання у процесі виховання та навчання займались С. Лібіх, Е. Рейдер та І. Шварц.

Психологічними явищами навіювання і самонавіювання займається галузь науки сугестологія. За визначенням Г. Лозанова, сугестологія $\epsilon$ «наукою про навіювання, яке розуміється не у вузькоклінічному, а в широкому, соціально-психологічному, аспекті», і $\epsilon$ «результатом поєднання педагогіки, медицини і мистецтва» [5]. Він застосував сугестію в педагогіці й розробив метод, який дозволив використовувати сугестивні впливи на особистість у звичайному стані свідомості для активізації резервних психічних можливостей особистості в навчальному процесі під час вивчення іноземних мов. Для здійснення сугестивного впливу застосовується певний ритм, паузи, авторитет педагога, його погляд та вираз обличчя, формування ним певних установок, відповідна інтонація, музичний фон, двоплановість, інфантилізація, концертна псевдопасивність. Відмінною рисою цього методу є поєднання усвідомлюваних і неусвідомлюваних компонентів психіки під час засвоєння та перероблення інформації. Принцип радості, ненапруженості та концентративної психорелаксації є головним у навчальній системі Г. Лозанова. Значну роль у цій системі відіграє підготовка викладачасугестолога, збереження емоційно-логічного балансу та глобалізація змісту навчального матеріалу з урахуванням закономірностей певного предмету у поєднанні з естетизацією, тобто використанням різних жанрів мистецтва під час навчання, а також передбачає міжпредметну глобалізацію тем. Дослідник називає свою навчальну систему десугестивно-сугестивною, оскільки, по-перше, необхідно звільнити учня від уявлень про його обмежені властивості, подруге, завдяки використанню сугестії стимулювати розвиток цілісної особистості.

Дослідники В. Belander-Popvassileva, W. J. Bancroft, Д. Матвєєв стосовно сугестопедії висловлюють думку, що Г. Лозанов створив не якісно нову навчальну систему, а зумів гармонійно поєднати в єдине ціле досягнення психології, психотерапії, фізіології та дидактики. Такий синтез дозволив розширити коло використання підходів до розкриття можливостей учнів, вихованні цілісних особистостей, змінити традиційну побудову навчально-виховного процесу $[6$, с. 30]. Г. Лозанов у своїй навчальній системі для розкриття резервних можливостей мозку під час сугестивного впливу виокремлює такі сугестивні явища, як: імперативність, швидкість, точність і економічність, автоматизацію. Однак особливу роль у навіюванні відводить неусвідомлюваній психічній активності. Дослідження, які проводились у цьому напрямку, сприяли відкриттю сугестопедичних центрів в Болгарії, Австрії, Німеччині, Канаді, США та країнах СНД.

Послідовниками сугестопедичної навчальної системи Г. Лозанова в колишньому СРСР були І. Шехтер Л. Гегечкорі Г. Китайгородська, В. Петрусинський та інші. Сугестопедичні підходи в кінці XX та на початку XXI століття використовуються педагогами-науковцями під час вивчення таких шкільних дисциплін, як: географія, природознавство, математика, історія, фізика, хімія, українська мова і має відображення у працях К. Гінбаясі, З. Даскалової, С. Пальчевського, А. Сиротенко, М. Чошанова.

Український дослідник С. Пальчевський у своєму вивченні й аналізі сугестопедичної літератури виокремлює чотири етапи в розвитку сугестопедагогіки та характеризує основні напрямки сугестопедагогіки - гіпнопедія, ритмопедія, релаксопедія і сугестопедія. Сугестопедичну систему Г. Лозанова дослідник модифікує та називає іiі ХЕТвоД (Художність, Емоційність, Творчість, Духовність). Навчальна модель складається з психолого-фізіологічних 
основ, дидактико-методичних основ і спрямована на розв'язання та гармонізацію суперечності між інтересами індивідуальними та загальними, яка виступає головною проблемою педагогічного процесу і полягає у найбільш повному розвитку генетично закладених творчих здібностей дитини за рахунок створення сприятливих умов навчання [6, с. 163-164].

Стосовно навчання у ВНЗ науковець С. Гончаров уважає, що вимоги до сучасних студентів $\epsilon$ досить високими, й тому стає зрозумілим, що рівень їхнього нервово-емоційного та розумового навантаження підвищується. На думку дослідника, застосування методу СОЕВКЛ (словесно-образне, емоційно-вольове керування стану людини) допоможе у розв'язанні складних завдань під час навчання.

Питанню сугестії в підготовці майбутніх музичних фахівців присвятили свою увагу такі дослідники, як: А. Козир, В. Петрушин, О. Полякова, Т. Рейзенкінд, В. Федоришин. А. Козир у запропонованій концептуальній моделі формування професійної майстерності майбутнього вчителя музики обгрунтовує систему педагогічних принципів, одним із яких $є$ принцип індивідуалізації. Він передбачає насамперед те, що кожен студент має свої особливості, які необхідно враховувати під час навчання. Важливим постає й добір та застосування сугестивних засобів впливу викладача на студента, що сприятиме максимальному розвитку творчих здібностей особистості. Дослідниця наголошує на необхідності розвитку сугестивних здібностей майбутнього вчителя музики як керівника хорового колективу для кращого розуміння, взаємодії, взаємозбагачення викладача з учнівським колективом і ефективного впливу та управління його творчою діяльністю. А. Козир було розроблено поетапну методику формування професійної майстерності майбутніх учителів музики. На проективно-творчому етапі пропонується застосування таких завдань-вправ сугестивного порядку, які б сприяли розвитку вольових якостей майбутніх учителів музики, вмінню створювати атмосферу психологічного комфорту в хоровому колективі [4, с. 18-23].

Професійна підготовка майбутнього вчителя музики $є$ багатоступеневим процесом, де чинне місце займає музично-виконавська діяльність. Зокрема В. Петрушин пропонує молодим музикантам-педагогам для зняття втоми, нервового психічного напруження, підвищення працездатності розвязання складних завдань вправи на медитацію та автогенне тренування.

В. Федоришин зазначає, що використання навіювання у діяльності майбутнього вчителя музики як керівника оркестрового колективу дозволяє зняти опір своїм творчим настановам, досягти бажаних результатів та повного взаєморозуміння між керівником та його колективом. Він уважає, що навіювальний вплив диригента на оркестровий колектив залежить від його сугестивних здібностей, від наявності вольових якостей, оволодіння різними типами психологічного впливу на творчий колектив [8, с. 47-51].

О. Полякова у своїх роботах, присвячених музично-педагогічній діяльності, розглядає вербальні й невербальні навіювання як стимул, що мають вплив на суб'єкта на несвідомому рівні. Спілкування між викладачем та майбутнім учителем музики здійснюється за допомогою вербального потоку, потоку зорової інформації, потоку тактильного діяння між викладачем i студентом на заняттях із музично-виконавських дисциплін, потоку мови музики, які мають сугестивний вплив.

Поняття «сугестія», «сугестивна технологія» у професійній підготовці майбутнього вчителя музики й мистецьких дисциплін висвітлено в семантичній моделі Т. Рейзенкінд. Модель складається 3 горизонтальної та вертикальної ліній. У семантичній моделі, запропонованою дослідницею, відбувається поєднання знань, умінь та навичок майбутніх учителів музики та мистецьких дисциплін у процесі навчання з використанням різних видів мистецтв на основі особистісно-діяльнісного підходу й сугестивного впливу. Ця модель передбачає стимулювання сфери свідомого і несвідомого, що впливає на формування образних уявлень, розвитку асоціативного мислення. Т. Рейзенкінд зауважує, що застосування гри, діалогу, взаємодії партнерів спілкування під час художньо-професійної діяльності 3 урахуванням сугестивного впливу значно підвищує ефективність навчання.

Дослідження питань сугестії науковцями різних напрямків дозволяє констатувати, що сугестія у психології сприяє розумінню людині свого внутрішнього стану, іiї пристосуванню до швидкоплинних змін у навколишньому середовищі. Звернення до сугестії у лікувальних цілях психотерапевтами дозволяє впливати на емоції, образи пацієнтів, допомагає відновити в пам'яті минуле, розв'язувати конфліктні ситуації, знайти вихід із депресії і зняти тривогу. 3 
позиції філософії дослідження цього феномену відтворюють чітку картину поведінки, бажань і прагнень людини, iii стосунки 3 іншими людьми та довкіллям. Вивчення сугестивною лінгвістикою різних параметрів сугестивних текстів дозволяє створювати спеціальні тексти, які впливатимуть на установки особистості. У педагогіці застосування сугестії в процесі вивчення різних шкільних дисциплін уможливлює розкриття резервних можливостей особистості, сприяє покращенню психічного стану учнів, ефективному засвоєнню навчального матеріалу. У дослідженнях, присвячених професійній підготовці майбутніх учителів музики та фахівців факультетів мистецтв, пропонується використання сугестивних засобів задля стимулювання фантазії, формування образного мислення, створення атмосфери психологічного комфорту між викладачем і студентами та сприяє розвитку творчих здібностей особистості.

Подальша перспектива дослідження полягає у визначенні особливостей застосування сугестивних впливів майбутніми вчителями музики у професійній діяльності.

\section{Література}

1. Бехтерев В. М. Внушение и воспитание / В.М. Бехтерев // Объективное изучение личности: Избранные труды по психологии личности в 2-х томах. - Санкт-Петербург: Алетейя, 1999. - Т. 2. 283 с. 2. Даль В. И. Толковый словарь живого великоруського язика / В.И. Даль. - Т. 1: А-3. - 1989. 699 с. 3. Журавлев А.П. Звук и смисл : [кн. для внеклас. чтения учащихся ст. классов] / А.П. Журавлев. - 2-е изд., испр. и доп. - М. : Просвещение, 1991. - 160 с. 4. Козир А. В. Теорія та практика формування професійної майстерності вчителів музики в системі багаторівневої освіти : автореф. на здобуття наук. ступеня докт. пед. наук : 13.00.02, 13.00 .04 / А. В. Козир. - Київ, НПУ ім. М.П. Драгоманова, 2009. - 40 с. 5. Лозанов Г. К. Суггестология и суггестопедия - теория и практика / Г. К. Лозанов - София, 1971. 6. Пальчевський С. С. Сугестопедагогіка : новітні освітні технології : [навч. посібник] / С. С. Пальчевський. - К. : Кондор, 2005. - 351 с. 7. Симонов П. Сознание, подсознание, сверхсознание / П. Симонов // Наука и жизнь. - № 12. - 1975. - С. 45-51. 8. Федоришин В. Вплив сугестивних факторів на фахове становлення керівника оркестрового колективу / В. Федоришин // «Молодь і ринок». - № 2 (73), 2011. - С. 47-51. 9. Фрейд 3. Я и Оно / 3. Фрейд. - М. : МПО «МЕТТЭМ», 1990. - 56 с. 10. Черепанова И. Ю. Человек манипулирующий (суггестия в коммуникации) / И. Ю. Черепанова // Человек говорящий: язык, культура, познание: [межвузовский сборник научных трудов] / [ред. А. А. Романов, А. М. Шахнарович]. - Москва-Тверь: Институт языкознания РАН, Тверской Институт экономики и менеджмента, 1995. - С. 115-123. 11. Чубукова Т. Сугестія і сугестопедія у навчальному процесі / Т. Чубукова // Історія в школі, 1998. № 1. - С. 8-11. 12. Юнг К.-Г. Психология бессознательного / К.-Г. Юнг. - М., 1994. -249 с.

УДК 378.147.315.6:37.04

Володимир Онопа

\section{НЕТРАДИЦІЙНІ ПІДХОДИ ДО ОСМИСЛЕННЯ РЕГУЛЯТИВНОЇ ФУНКЦІї ПРИНЦИПУ ГРУНТОВНОСТІ ЗНАНЬ}

Онопа В. М. Нетрадиційні підходи до осмислення регулятивної функції принципу грунтовності знань.

У статті, у контексті аналізу регулятивної функції принципу грунтовності знань, розглядаються недостатньо вивчені положення, які стосуються засадничих гносеологічних умов досягнення грунтовного засвоєння людиною інформації. На грунті узагальнення досягнень сучасної сугестопедії визначаються загальні передумови моделювання психічних станів людини, подібних до натхнення; стимулювання уваги, повноцінного використання можливостей не лише усвідомлюваного напруженого зосередження, а й випадкових (зокрема периферичних) перцепцій.

Ключові слова: принципи дидактики, дидактичні умови грунтовного засвоєння знань, сугестопедія, моделювання психічних станів, інтуїція.

Онопа В. М. Нетрадиционные подходы к осмыслению регулятивной функции принципа основательности знаний.

В статье, в контексте анализа регулятивной функции принципа основательности знаний, рассматриваются недостаточно изученные положения, касающиеся основополагающих гносеологических условий достижения прочного усвоения человеком информации. На основании обобщения достижений современной суггестопедии определяются общие предпосылки 